\title{
LANDASAN TEOLOGI PRAKTIK RITUAL HINDU
}

\author{
Oleh : \\ I Gusti Ketut Widana \\ igustiketutwidana1805@gmail.com \\ Dosen Fakultas Pendidikan, UNHI Denpasar
}

I Gusti Ayu Suasthi

Dosen Fakultas Pendidikan, UNHI Denpasar

\begin{abstract}
ABSTRAK
Pada dasarnya, aktivitas ritual adalah serangkaian perbuatan sakral (suci/keramat) yang dilakukan umat Hindu dengan menggunakan alat-alat tertentu, tempat, dan cara-cara tertentu. Fungsi pokoknya adalah sebagai media berserah diri dengan menyembah Tuhan beserta manifestasi-Nya disertai berbagai persembahan seraya diiringi doa-doa (mantra) guna mendapatkan suatu anugrah keselamatan. Ritual-ritual Hindu yang sering dilaksanakan dalam kehidupan sehari-hari pada umumnya merupakan ritual siklus kehidupan seperti ritual kelahiran, perkawinan, hingga kematian yang secara emosi keagamaan sangat diyakini sesuai dengan landasan teologinya. Bahwa secara teologi, agama Hindu dikonstruksi tiga kerangka dasar dengan memosisikan "ritual" (acara) sebagai suplemen material (kulit/kemasan) untuk menunjang elemen "etika" (susila) sebagai bagian esensi yang diperkuat sekaligus untuk menguatkan pondamen "filsafat" (tattwa) sebagai substansi.

Kata kunci : teologi, praktik, ritual
\end{abstract}

\section{ABSTRACT}

Basically, ritual activities are a series of sacred (sacred / sacred) actions carried out by Hindus using certain tools, places, and certain ways. Its main function is as a medium to surrender by worshiping God along with His manifestations accompanied by various offerings while accompanied by prayers (mantras) in order to obtain a gift of salvation. The rituals that are often encountered and experienced and carried out in daily life are generally life cycle rituals such as the rituals of birth, marriage, until death that are religiously believed by followers. Hinduism itself as a religion constructed by three basic frameworks positions "ritual" (event) as a supplement of material (skin / packaging) to support the element of "ethics" (moral) as part of an essence that is strengthened as well as to strengthen the foundation of "philosophy" (tattwa) as substance.

Keywords: theology, practice, ritual 


\section{PENDAHULUAN}

Ada banyak definisi tentang istilah "teologi" ini, namun pada hakikatnya semua terminologi itu mengarah pada satu pengertian, yaitu pengetahuan tentang "Tuhan". Sebagaimana pendapat seorang teolog besar dari Roma Katholik yang bernama Albert, ia menguraikan bahwa; Istilah "teologi" secara harfiah berarti 'studi mengenai Allah', yang berasal dari kata Yunani theos. yang berarti 'Tuhan', dan akhiran 'ology' dari kata Yunani logos yang berarti (dalam konteks ini) 'wacana', 'teori', atau 'penalaran'. Selain definisi tersebut pendapat lain yaitu Agustinus dari Hippo mendefmisikan bahwa teologi berasal dari bahasa Latin, yaitu 'theologia', sebagai 'penalaran atau diskusi mengenai

Ketuhanan'. Richard Hooker mendefinisikan "theology" dalam bahasa Inggris sebagai "ilmu tentang hal-hal yang ilahi". Juga secara umum, teologi adalah studi iman agama, praktik, dan pengalaman, atau spintualitas (Donder, 2009: 1).

Masih dalam hubungannya dengan definisi teologi, menjadi sangat penting mengutip pandangan Dister OFM (2007: 1 7) bahwa :

"Istilah teologi berasal dari bahasa Yunani yaitu dari kata theologia yang berarti ilmu (logia) tentang Allah (Theos, Tuhan). Untuk memahami dengan lebih mendalam apa yang dimaksud dengan istilah "teologi" dalam lingkungan Kristiani, khususnya dalam Gereja Kristen-Katolik, maka keterangan etimologi di atas tidak mencukupi. Untuk itu perlu dimengerti apa hakikat teologi itu. Hakikat atau intisari dari sesuatu hal dirumuskan dalam sebuah "definisi" atau "batasan". Teologi adalah pengetahuan adi-kodrati yang metodis, sistematis, dan koheren tentang apa yang diimani sebagai wahyu Allah atau berkaitan dengan wahyu itu. Teologi harus dlgolongkan dalam kegiatan intelektual manusia yang disebut "tahu" dan "mengetahui". Akan tetapi, berbeda dengan pengetahuan harian, pengetahuan teologi bersifat metodis, sistematis dan koheren atau "bertalian". Ini berarti teologi merupakan pengetahuan yang bersifat ilmiah".

Kata teologi itu sendiri di dalam Hindu disebut dengan istilah Brahmavidva yang telah dirumuskan pada masa kehidupan Maharsi Vyasa atau sezaman dengan peristiwa besar Mahabharata sebagaimana pendapat Ramanuja. Ini berarti Brahmavidva (teologi) dalam Hindu itu sesungguhnya sudah ada 5000 tahun yang lampau. Sebab peristiwa penobatan Parikesit yaitu cucu Arjuna menjadi raja Hastina Pura terjadi pada tanggal 18 Februari 3102 SM. Sri Vyasa Maharsi penyusun Brahma Sutra yang tak lain adalah Brahmavidya hidup pada zaman itu. Sehingga Brahmavidya (Teologi) dalam Hindu juga sudah sangat 
tua usianya, yaitu telah berumur 5109-an tahun (Titib, 1996: 7).

\section{PEMBAHASAN}

\subsection{Landasan Teologi}

Berpijak pada definisi teologi (Brahmavidya) di atas, dikaitkan dengan landasan teologi dari aktivitas ritual umat Hindu, maka korelasinya berhubungan erat dengan dasar-dasar kepercayaan/keyakinan (sradha) umat Hindu kepada Ida Sanghyang Widhi Wasa/Tuhan Yang Maha Esa. Menelisik kata "Sradha”, dikatakan berasal dari akar kata "Srat" atau "Srad" yang artinya "hati", lalu mendapat tambahan kata "dha” yang berarti “meletakkan/menempatkan". Jadi,kata "Sradha" mengandung arti "menempatkan hati seseorang pada sesuatu" (Subagiasta, 2006: 47). Pustaka Wajasaneyi Samhita, menyatakan bahwa Sradha adalah "kebenaran", sebaliknya Asradha berarti "kepalsuan".

Selanjutnya, Subagiasta (2006: 48) menyatakan bahwa fungsi Sradha bagi setiap umat Hindu adalah: Pertama, sebagai kerangka dasar/pondasi Dharma. Ibarat membangun sebuah perumahan agama Hindu, kerangkanya adalah Sradha. Karena itu Sradha mewujudkan bentuk lahir dari agama Hindu sebagai penyangga bangunan rumah. Kedua, sebagai alat/sarana dalam mengatur manusia menuju kepada Tuhan. Pengertian ini dapat dilihat dalam kitab Yajur Weda XIX, 30 yang menyatakan: Sraddhaya satyam apyati (dengan Sradha orang akan mencapai Tuhan), Sraddham satye prajapatih (Tuhan menetapkan, dengan Sradha menuju pada Satya).

Jelas sekali, Sradha menempati posisi penting dalam keyakinan umat Hindu. Bagi umat yang tidak memiliki kepercayaan/keyakinan (sradha) juga dengan tegas dinyatakan konsekeunsinya, seperti tersurat di dalam kitab suci Bhagawadgita, IX. 3,:

"Asraddadhanah purusha
dharmasyasya parantapa
aprapya mam nivartante
mrityu-samsara-vartmani"

Maknanya :

'Orang yang tidak memiliki keyakinan dengan cara ini tak akan mencapai Aku, wahai Paramtapa (Arjuna), dan akan kembali ke dunia kehidupan fana (samsara)' (Pudja, 1981: 206)

Sementara itu bagi umat yang dengan sungguh dan teguh menguatkan sradha untuk berbhakti kepada Ida Sanghyang Widhi/Tuhan Yang Maha Esa dengan segala sifatnya (guna)semua itu akan dapat mengantarkan umat pada-Nya. Berikut 
ini secara berturut-turut, Pudja (1981: 283-

289 dan 294) dalam kitab suci

Bhagawadgita, XII. 2-11, dan 20

menyajikan suratan sloka-slokanya, yaitu :

"Sri-bhagavan uwaca

mayy awesya mano ye mam

nitya-yukta upasate

sraddhaya "paraya "petas

te me yuktatama matah"

Maknanya :

'Sri Bhagavan bersabda:Mereka yang memusatkan pikirannya pada-Ku dengan menyembah-Ku dan senantiasa bersungguhsungguh serta memiliki keyakinan yang sempurna, merekalah yang Aku anggap paling sempurna dalam yoga'.

"Ye tw aksharam anirdesyam

awyaktam paryupasate

sarwatra-gam acintyam ca

kuta-stham acalam dhruvam;

Sanniyamyendriya-gramam

sarvatra sama-buddhayah

te prapnuvanti mam eva

sarva-bhuta-hite ratah"

\section{Maknanya :}

'Tetapi mereka yang memuja Yang Abadi, Yang Tak Terdefinisikan, Yang Takberwujud, Yang Mahaada, Yang Takterpikirkan, Yang Takberubah dan Yang Tak Tergerakkan, Yang Konstan; Dengan menahan semua indra, senantiasa mantap dalam segala kondisi, senang dalam mensehjaterakan segala mahluk, mereka sesungguhnya datang kepada-Ku'

Tesam aham samuddharta mrityu-samsara-sagarat bhawami na cirat partha

mayy awesita-cetasam"

Maknanya :

'Tetapi mereka yang menyerahkan segala kegiatannya pada-Ku, bersungguh-sungguh kepada-Ku, memuja dan bermeditasi kepada-Ku, dengan pengabdian yang tak tergoyahkan; Yang pikirannya tertuju pada$\mathrm{Ku}$, dengan langsung dan segera Aku entaskan mereka dari lautan samsara (belenggu kelahiran dan kematian), wahai Partha (Arjuna)'.

"Athai 'tad apy asakto 'si kartum mad-yogam asritah sarwa-karma-phala-tyagam tatah kuru yatatmavan"

Maknanya :

'Bila yang inipun tak dapat kamu lakukan, maka berlindunglah dalam kegiatan-Ku yang terdisiplinkan, lepaskan hasil dari segala kegiatan kerja dengan memasrahkan dirimu'.

"Ye tu dharmamritam idam
yathoktam paryupasate
sraddadhana mat-parama
bhaktas te 'tiwa me priyah"

Maknanya :

'Tetapi, mereka yang penuh keyakinan memandang-Ku sebagai tujuannya yang tertinggi, mengikuti kebijaksanaan abadi ini, bhakta yang demikian itulah yang paling Aku sayangi'. 
Atas dasar Sradha atau keyakinan sebagaimana telah disuratkan di dalam beberapa sloka Bhagawadgita di atas, maka tiada kata lain bagi umat Hindu untuk selalu memuja, mengagungkan dengan mengabdikan diri melalui bhakti agar mendapat perlindungan dari-Nya, sebagaimana tersurat pada kitab

Bhagawadgita, IX. 14, 22-23, dan 34 :

"Satatam kirtayanto mam yatantas ca drdha-vratah namasyantas ca mam bhaktya nitya-yukta upasate"

\section{Maknanya :}

'Dengan memuliakan Aku senantiasa, rajin dan mantap dalam sumpah, bersujud kepada-Ku dengan penuh pengabdian, mereka memuja-Ku dengan penuh disiplin'.

\section{"Ananyas cintayanto mam ye janah paryupasate tesham nityabhiyuktanam yoga-ksemam wahamy aham" \\ Maknanya :}

'Tetapi, mereka yang memuja-Ku dan hanya bermeditasi kepada-Ku saja, kepada mereka yang senantiasa gigih demikian itu, akan Aku bawakan segala apa yang belum dimilikinya dan akan menjaga apa yang sudah dimilikinya'.

\section{"Ye 'py anya-dewata-bhakta yajante sraddhaya 'nvitah te 'pi mam eva kaunteya yajanty awidhi-purwakam"}

\section{Maknanya :}

'Bahkan mereka yang merupakan bhakta dari para dewa lain, yang memujanya dengan penuh keyakinan, mereka juga sebenarnya hanya memuja-Ku, wahai putra Kunti (Arjuna), walaupun tidak sesuai dengan hukum ajaran yang sebenarnya'.

\section{"Manmana bhawa madbhakto madyaji mam namaskuru mam ewaishyasi yuktvai 'wam atmanam mat-parayanah"}

Maknanya :

'Pusatkan pikiranmu pada-Ku, berbhaktilah pada-Ku; puja dan tunduklah pada-Ku, dan dengan mendisiplinkan dirimu serta menjadikan-Ku sebagai tujuan, engkau akan sampai kepada-Ku' (Pudja, 1981: ,212, 217, 218, 224).

Demikian secara tekstual dasar Sradha umat Hindu yang mendorong emosi keyakinannya berperilaku keagamaan dalam bentuk aktivitas ritual yang dilandasi teologi Hindu (Brahmavidya) serta bersifat supra empiris (transenden) dan kemudian mengimanensi secara kongkrit melalui sikap "tunduk/taat" (bhakti) kepada Sang Pencipta, Ida Sanghyang Widhi Wasa/Tuhan Yang Maha Kuasa. Bagi umat Hindu, posisi keyakinan (sradha) memang menempati hierarki paling tinggi sekaligus mendasar sebagai pondasi keimanan dalam kehidupan beragama. Kekuatan dalam keyakinan 
(sradha) inilah yang menjadikan umat Hindu begitu tekun, taat dan tunduk terhadap prinsip dasar teologis sehingga menjadikan ekspresi bhaktinya melalui aktvitas ritual tak pernah surut dilaksanakan.

\subsection{Panca Sradha, Sebagai Dasar} Keyakinan

Berbicara tentang landasan teologi Hindu, berkaitan erat dengan sradha, yang meliputi lima dasar keyakinan yang disebut Panca Sradha, meliputi :

\section{1) Keyakinan kepada Tuhan (Brahman)}

Brahman adalah Roh yang paling tinggi, diluar jangkauan manusia, tidak terbatas oleh ruang dan waktu (Keene, 2006 :18). Ia adalah sinar roh yang selalu murni. Ia adalah sat cit ananda, Esa tanpa duanya. Ia adalah Bhuma (tak terbatas dan tak terkondisikan). Ia bersemayam dalam hati manusia. Di dalam Weda disebut Iswara, dalam Whraspati Tatwa disebut Paramasiwa dan dalam lontar Purwabhumi Kemulan disebut Sanghyang Widhi Wasa (Cudamani, 1993, 65). Apapun nama-Nya tetapi yang dimaksud adalah Beliau yang merupakan asal mula, pencipta, dan tujuan akhir dari seluruh alam semesta ini. Beliau disebut "Sat", sebagai Maha Ada Satu- satunya, tidak ada keberadaan yang lain di luar beliau. Jika demikian, pada hakikatnya hanya ada satu zat, yakni "Sat", yang "Ada". "Sat" ini dapat disebut Prajapati, ia tiada dibayangkan sebagai suatu Dewa yang berpribadi, yang berdiri di luar dunia, melainkan adalah "dasar segala hal" yang tidak berpribadi. Untuk menyatakan "dasar segala hal" itu Upanishad-upanishad selalu memakai istilah "Brahman" (Cudamani, 1993, 67).

Brahman dalam agama Hindu (Bali) disebut juga Ida Sanghyang Widhi, adalah Beliau yang Menakdirkan, Yang Maha Kuasa, dan Sang Pencipta semua yang ada, serta menjadi segala sumber dari segala yang ada dan tiada (Pudja, 1977: 25).Tuhan Ada dan meng-Ada, meresap di semua tempat dan mengatasi semuanya (Wyapi Wyapaka Nirwikara). Kitab Brahman Sutra menyatakan "Janma Dhyasya Yatah" artinya Ida Sanghyang Widhi adalah asal mula dari semua yang ada di alam semesta ini, mulai dari penciptaan (utpethi), pemeliharaan (sthiti) hingga peleburan (pralina). Agama Hindu merupakan agama monoteis yang hanya menyembah pada satu Tuhan meskipun banyak Dewa yang melindungi. Tentang Hindu monotheisme (ber-Tuhan Yang Satu), di dalam beberapa 
sumber teks telah ditegaskan, diantaranya, Pustaka Chandogya Upanishad menyatakan : "Om tat Sat Ekam Ewa Adwityam Brahman" artinya Ida Sanghyang Widhi hanya satu tak ada duanya dan maha sempurna. Melalui mantram Tri Sandhya tersurat kata-kata :"Eko Narayanad na Dwityo Sti Kascit”, artinya hanya satu Ida Sanghyang Widhiyang disebut Narayana, sama sekali tidak ada duanya. Kutipan kitab Suci Reg Weda juga menyuratkan : "Om Ekam Sat Wiprah Bahuda Wadanti " artinya Ida Sanghyang Widhi itu hanya satu, tetapi para arif bijaksana menyebutnya dengan berbagai nama. Selanjutnya di dalam petikan kakawin Sutasoma ditegaskan : "Bhineka Tunggal Ika Tan Hana Dharma Mangrwa", artinya berbeda-beda tetapi satu, tak ada Ida SanghyangWidhi yang ke dua (Subagiasta, 2015: 53)

Melalui kutipan atau petikan teks beberapa kitab/pustaka suci di atas menegaskan bahwa agama Hindu adalah panganut monotheisme, meski dalam praktik keagamaannya lebih menampakkan sisi-sisi teologi manifestasi yang memosisikan Ida Sanghyang Widhi Wasa dalam fungsinya sebagai perwujudan (prabhawa), dengan sebutan sinar suci Tuhan atau Dewa/Bhatara yang lebih dekat dalam konsep pemujaan umatnya. Dikaitkan dengan aktivitas ritual umat Hindu, memberi pemahaman bahwa perilaku umat Hindu dalam melaksanakan kewajiban beragama sepenuhnya didorong keyakinannya yang (sangat) tinggi pada Ida Sanghyang Widhi Wasa/Tuhan Yang Maha Kuasa. Sehingga sebagai realisasi Sradha melalui bhaktinya, termasuk dalam bentuk aktivitas ritual diyakini merupakan wujud pelaksanaan "perintah Tuhan" yang sedikitpun tak kuasa bagi hamba-Nya untuk mengabaikan apalagi berani meninggalkannya. Bagi umat Hindu melaksanakan aktivitas ritual merupakan kewajiban mendasar yang diyakini besar pula phahalanya.

\section{2) Keyakinan Adanya Atman}

Atman adalah percikan kecil dari sinar suci Brahman (Ida Sang Hyang Widhi Wasa). Atman berasal dari kata "An" yang berarti bernafas. Setiap makhluk yang bernafas mempunyai Atman, sehingga mereka dapat hidup. Jadi Atman adalah nafasnya semua makhluk hidup baik itu manusia, hewan, maupun tumbuhan. Atman berasal dari Brahman (Tuhan/Ida Sanghyang Widhi Wasa) yang memberikan hidup kepada semua makhluk di muka bumi ini. Badan kita tidak akan berfungsi bila di 
dalam tubuh tidak ada Atman yang memiliki sifat-sifat seperti berikut : (a) acchedya berarti tak terlukai senjata; (b) adahya berarti tak terbakar oleh api; (c) akledya berarti tak terkeringkan oleh angina; (d) acesya berarti tak terbasahkan oleh air; (e) nitya berarti abadi; (f). sarwagatah berarti ada di mana-mana; (g) sathanu berarti tidak berpindah-pindah; (h) acala berarti tidak bergerak; (i) awyakta berarti tidak dilahirkan; (j) achintya berarti tak terpikirkan; (k) awikara berarti tidak berubah; (1) sanatana berarti selalu sama (Saraswati, 1993: 79).

Oleh karena Atman berasal dari Brahman, maka sejatinya Atma itu sifatnya suci dan sempurna. Tetapi pertemuan antara Atma dengan badan yang kemudian menimbulkan ciptaan menyebabkan Atma dalam keadaan "Awidya". Awidya artinya gelap atau lupa kepada kesadaran. Awidya muncul karena pengaruh unsur panca maha bhuta yang mempunyai sifat duniawi. Sehingga dalam hidup ini Atma dalam diri manusia di dalam keadaan Awidya (Subagiasta, 2006: 68).

Untuk itulah hakikat hidup dan berkehidupan adalah bertujuan untuk menghilangkan Awidya sehimngga bisa mencapai kesadaran sejati dengan cara melaksanakan Subhakarma berdasarkan tuntunan Dharma. Menyadari sifat Atma yang serba sempurna dan penuh kesucian menimbulkan usaha untuk menghilangkan pengaruh Awidya tadi. Karena apabila manusia meninggal kelak hanya badan yang rusak, sedangkan Atmanya tetap ada, dan akan kembali mengalami kelahiran berulang dengan membawa bekal "karma wasana" (bekas hasil perbuatan). Oleh karena itu, kelahiran sebagai manusia kedunia ini dituntun ajaran agama untuk senantiasa berbuat baik dan benar atas dasar pengabdian untuk membebaskan Sang Atma dari ikatan duniawi hingga nantinya dapat manunggal pada Sang Brahman (Brahman Atman Aikyam).

\section{3) Keyakinan Adanya Karmaphala}

Merujuk Sivananda (1993:103), secara etimologi kata "Karmaphala" berasal dari dua kata yaitu "karma" dan "phala". Karma artinya 'perbuatan' sedangkan phala berarti 'hasil'. Jadi Karmaphala artinya hasil suatu perbuatan yang dilakukan seseorang. Karmaphala ini sesungguhnya merupakan hukum sebab akibat, bahwa setiap perbuatan yang dilakukan pasti akan mendapatkan buahatau hasilnya. Berdasarkan kurun 
waktunya, secara garis besar ajaran Karmaphala dibagi menjadi tiga yaitu :

(a) Sancita Karmaphala, artinya bahwa setiap perbuatan yang dilakukan pada masa masa/kehidupan lalu akan menerima atau menikmati hasilnya pada kehidupan sekarang.

(b) Prarabda Karmaphala, artinya bahwa setiap perbuatan yang dilakukan pada masa/kehidupan sekarang akan menerima dan menikmati hasilnya pada kehidupan sekarang juga.

(c) Kryamana Karmaphala, artinya bahwa setiap perbuatan yang dilakukan pada masa/kehidupan sekarang pada kehidupan yang akan datang kita menerima hasil dari perbuatan tersebut.

Melalui keyakinan akan adanya hukum Karmaphala ini, memberikan kesadaran bahwa setiap perbuatan yang dilakukan di dunia ini, baik atau buruk akan memberikan hasil. Tidak ada perbuatan sekecil apapun yang luput dari hasil, cepat atau lambat, langsung maupun tidak langsung pahalanya pasti akan datang juga. Diyakini bahwa perbuatan yang baik (Subhakarma) akan membawa hasil yang menyenangkan atau membahagiakan. Sebaliknya perbuatan yang buruk (Asubhakarma) dengan sendirinya akan membawa hasil yang serba tidak menyenangkan apalagi membahagiakan.

Titib (2009: 93) menambahkan bahwa perbuatan-perbuatan buruk (Asubhakarma)itulah yang nantinya menyebabkan Sang Atma jatuh ke Neraka, dimana ia mengalami segala macam siksa derita. Bila hasil perbuatan Asubha karma itu sudah habis diterima dalam bentuk siksa derita, maka ia akan menjelma kembali ke dunia sebagai makhluk yang bisa jadi lebih rendah dari tingkatan atau derajat manusia. Namun, bila perbuatan-perbuatan yang dilakukan sepenuhnya baik (Subhakarma) maka pahala yang diterima adalah berupa berbagai kebahagiaan hidup termasuk kelak menikmatinya di sorga. Setelah hasil perbuatan-perbuatan baik itu sudah habis dinikmati, ternyata tetap juga tak terhindarkan dari siklus Punarbhawa, yaitu mengalami reinkarnasi atau penjelmaan (panumadian) kembali ke dunia, bahkan bisa berulang-ulang, tentunya dengan keadaan yang diharapkan semakin bertambah baik, sejahtera dan membahagiakan. 


\section{4) Keyakinan Adanya Punarbhawa}

Mengutip Wiratmadja dan Nala (1977: 71) kata "Punarbhawa" berasal dari dua kata yaitu "Punar" dan "bhawa". "Punar" berarti 'kembali' dan "bhawa" berarti 'menjelma' (lahir). Jadi, Punarbhawa artinya kelahiran atau penjelmaan kembali secara berulang-ulang (reinkarnasi). Istilah Punarbhawa sering juga disebut Samsara yang artinya lahir kembali ke dunia berulang-ulang kali. Kelahiran kembali ini terjadi karena Sang Atma masih diliputi oleh keinginan dan kemauan yang berhubungan dengan keduniawian, yang tentunya tidak lepas dari keadaan sengsara, sebagai hukuman yang diakibatkan oleh perbuatan atau karma di masa kelahiran yang lampau. Adapun jangka waktu pembebasan Sang Atma dari keadaan Samsara (sengsara) itu sangat tergantung pada perbuatan baik kita pada masa lampau (atita), sekarang (wartamana) dan akan datang (nagata).

Itulah sebabnya, secara kodrati sebenarnya kehidupan di dunia ini adalah untuk tujuan berbenah menyempurnakan kualitas diri. Dasar pemahamannya bahwa pada setiap kehidupan di masa lalu disadari ataupun tidak masih belum sempurna. Artinya, masih banyak membuat dan membawa kesalahan atau sisa dosa yang belum tuntas apalagi lunas dibayar. Sehingga pertanggungjawabannya wajib dilakukan pada setiap masa kehidupan, bisa pada masa kehidupan sekarang, atau pada kelahiran yang akan datang. Semuanya sangat tergantung pada apa yang dilakukan dalam bentuk karma yang lalu, sekarang dan akan datang. Sampai suatu saat nanti Sang Atman terbebas dari segala ikatan bekas perbuatan (karmawasana), sehingga bisa mencapai pembebasan atau kalepasan (moksa), yang sama artinya tidak lagi mengalami siklus lahir-hidup-mati.

\section{5) Keyakinan Adanya Moksa}

Secara konseptual, Moksa adalah obsesi umat Hindu dalam mencapai tujuan akhir kehidupan. Kata "Moksa" berasal dari kata "muc" yang artinya'bebas'. Bebas dari segala ikatan karma, atau ikatan maya, bebas dari berbagai ikatan duniawi dengan segala suka dan dukanya. Keadaan Moksa inilah yang sering disebut sebagai suatu keadaan dimana rasa suka tidak akan tersentuh lagi oleh kedukaan (suka tanpawali duka). Secara Tattwa keadaan Moksa digambarkan bahwa Sang Atman sudah kembali mencapai persatuan dengan Sang Brahman (Amor ring Acintya). Atman telah manunggal dengan Sang Asal yang 
Kekal yaitu Brahman itu sendiri (Brahman

Atman Aikyam) (Pudja, 1984: 62)

Selanjutnya, Punyatmadja (1989: 84)

menambahkan bahwa apa yang disebut keadaan Moksa itu terbagi lagi menjadi empat (4) tingkat pencapaian, yaitu :

(a) Samipya, yaitu tingkatan Moksa yang dapat dicapai oleh para Maha Rsi/Yogi dengan kematangan dan kesempurnaan tapa brata yoga samadhi, membuka intuisi rohani tingkat tinggi sehingga dapat menerima energy illahi berupa wahyu,sekaligus memahami hakikat kesejatian hidup dan kehidupan di dunia ini.

(b) Sarupya/Sadarmya, yaitu Moksa yang dapat dicapai oleh kesadaran sejati ketika Sang Atman dapat mengatasi segalanya. Tingkatan Moksa ini hanya dapat dicapai oleh sosok Awatara yang bisa mengatasi segalanya dan dapat menentukan sendiri kapan saatnya akan meninggalkan dunia ini.

(c) Salokya, yaitu tingkatan Moksa yang dapat dicapai oleh Sang Atman yang telah mampu mencapai tingkatan alam Brahman (Tuhan).

(d) Sayujya, adalah tingkat kebebasan yang paling tinggi bahkan sempurna, dimana Sang Atman telah bersatu atau mamnunggal pada Brahman (Brahman Atman Aikyam).

Sebenarnya keadaan Moksa bisa juga dicapai manusia semasa masih hidup di dunia, yang lazim disebut Jiwan Mukti. Namun mencapai keadaan dan tingkatan Jiwan Mukti tentu tidak mudah, pastinya memerlukan penyempurnaan kualitas Sradha dan Bhakti umat dengan senantiasa mematuhi dan melaksanakan segala ajaranNya sebagaimana diperintahkan di dalam kitab/pustaka suci.

\section{PENUTUP}

Berpijak pada paparan tentang landasan teologis di atas, tampak dengan jelas bahwa pelaksanaan aktivitas ritual umat Hindu, termasuk yang dilakukan di Pura Agung Jagatnatha Denpasar, tidak lepas dari adanya suatu keyakinan (Panca Sradha) sebagai pondasi pertama dan utama. Bahwa aktvitas ritual yang dilakukan adalah dalam rangka penguatan keyakinan/kepercayaan atau keimanan umat Hindu kehadapan Ida Sanghyang Widhi/Tuhan Yang Maha Esa selaku Sang Pencipta (utpeti), Pemelihara (utpeti) dan Pelebur (pralina). Dimana terciptanya dunia beserta segala isinya ini terjadi berkat Yadnya dari Tuhan itu sendiri, sehingga 
keterpeliharaan

atau

keberlangsungannyapun sudah menjadi hutang moral (Rna) umat Hindu untuk membayarnya melalui Yadnya juga.

Hanya dengan begitu, umat Hindu yang hakikatnya adalah Sang Atman akan dapat kembali pada Sang Brahman (Tuhan), dengan jalan banyak berbuat baik (Subhakarma), menghindari perilaku buruk (Asubhakarma) sehingga kelak berbuah manis yaitu tidak lagi mengalami Samsara dalam siklus Punarbhawa (reinkarnasi), tetapi dapat mencapai obsesi tertinggi berupa pembebasan atau kalepasan (Moksa).

\section{DAFTAR RUJUKAN}

Cudamani. 1993. Pengantar Agama Hindu. Jakarta: Hanuman Sakti.

Donder, I Ketut. 2009. Teologi: Memasuki Gerbang Ilmu Pengetahuan Ilmiah tentang Tuhan Paradigma Sanatana Dharma. Surabaya : Paramita.

Dister Ofm, Nico Syukur. 2007. Pengalaman dan Motivasi Beragama.

Yogyakarta : Kanisius.
Keene, Michael. 2006. Agama-agama Dunia. Yogyakarta: Kanisius.

Pudja, G. 1981. Bhagawadgita (Pancama Weda). Jakarta : Mayasaari.

Pudja, G. 1984. Sraddha, Pengantar Agama Hindu (cetakan II). Jakarta : Mayasari.

Punyatmadja, I.B. Oka. 1989. Panca Cradha. Jakarta : Yayasan Dharma Sarathi.

Saraswati, Sri Chandrasekharendra.1993. Aspek-Aspek Agama Hindu, Seputar

Weda dan Kebajikan (disadur oleh Nyoman S. Pendit).. Jakarta : Manikgeni.

Sivananda, Sri Swami. 1993. Intisari Ajaran Hindu. Surabaya : Paramita.

Subagiasta, I Ketut. 2006. Saiva Siddhanta di India dan di Bali. Surabaya : Paramita.

Subagiasta, I Ketut. 2015. Filsafat Saiva Siddhanta. Surabaya : Paramita.

Titib, I Made. 2009. Teologi \& SimbolSimbol dalam Agama Hindu. Surabaya : Paramita.

Wiratmadja, I Gusti Ketut Adia, dan I Gusti Ngurah Nala. 1977. Murdha Agama Hindu (Indonesia). Yogyakarta : Tanpa Penerbit. 